Occhisional Notes on Plants Indigenous in the immediate Neighbourhood of Sydney. No. 5.

By E. Haviland.

This paper consists of a few notes on Myrsine variabilis; a tree belonging to the order Myrsinaceæ. I am indebted to our friend, Mr. Deane, for all the specimens of the flowers and fruit of the plant that I have examined; for although I visited the locality with him, we could not at the time, find any tree, bearing flowers.

Of the genus Myrsine; Bentham, writing in 1869, gives but four species, but Von Mueller in his census of Australian plants, just published, enumerates six species ; of which, three are peculiar to Queensland; one common to Queensland and New South Wales ; one to Tasmania and New South Wales; and one peculiar to New South Wales.

Myrsine variabilis, in favorable localities, is a tree attaining a height of 30 to 40 feet. Its flowers are very small, certainly not exceeding one or one and a-half lines in diameter; and grow in small clusters in the axils and internodes of the leaves. I do not know to which of its peculiarities $R$. Brown referred, when in the year 1810 he gave it its specific name; but certainly none could be more appropriate. Indeed it varies so much, that I have found, from the same tree, flowers with five lobes to the corolla and five to the calyx; some with four lobes to each; some with five to the corolla and four to the calyx ; and others with four to the corolla and five to the calyx ; but in every case, the number of stamens has been the same as that of the lobes of the corolla. Again, I have found flowers with perfect ovaries and ovules, and with anthers full of pollen; and from the same plant, others without ovules, with stamens and fully developed anthers, but entirely without pollen.

It was while examining the flower in the endeavour to identify it, that my attention was directed to its peculiar construction. The corolla, which, as I have said, is not more than one line or one 
and a-half lines in diameter, is nearly or quite globular; and, so far as I have seen, always closed. The lobes, although divided to fully two-thirds of their whole length, keep so closely together, as to give the flower the appearance of a minute ball that has been cut in different directions across the top, but without causing the parts to gape or separate. If the corolla is taken off one of the most perfect flowers, slit open, and pinned, with insect pins, to a flat piece of cork, it can not only be examined and studied, with the stamens, anthers and pollen together; but it can be readily transferred to the stage of the microscope. It will be found to have five broadly acute lobes, thick, fleshy, and very concave; and having the stamens, which rise from the base, closely adnate with the lobes, nearly their whole length; bearing the anthers deep in the concavities, but sufficiently high on the lobes to be brought, owing to their dome shape, exactly over the stigma. The anthers are very large as compared with the rest of the flower, and peculiarly shaped, very broad at the base and tapering to a point at the apex. In fact, I cannot help comparing them to a chemist's precipitating glass, on a small scale. Owing to this peculiar form, the pollen, which is very dry and loose when fully ripe, falls without being impeded by the walls of the anther; and this is facilitated by the anther opening, not only in a longitudinal slit, but across the base, and gaping widely, so that it becomes quite empty at once. The style is very short, so that the stigma is almost sessile. Here too a great variation occurs. In those flowers which had imperfect ovaries, and no ovules, I have found the style solid throughout; but in the perfect flowers, having ovules, it appears to be simply a short hollow tube, with the stigma marginal. In fact, the ovary and style may aptly be compared with a globular shaped bottle, having a short, wide, open neck, in which case the stigma will answer for the rim or tip of the neck. In several cases I could, with a low power, see through the open tubular style, down into the ovary. I have found the tube partly filled with pollen, and I have also found pollen in the ovary, which must have fallen from the anthers directly through the tubular style. For, sometimes I thought it just possible, 
that the fovilla might be discharged by the pollen grains directly upon the foramen of the ovule, as occurs in a genus of not very dissimilar construction, in the Gymospermous order Gnetaceæ, but subsequent examination proved that this could not be so. Measuring, in four or five flowers, the diameter of the tube of the style by the micrometer eye piece, I found it to be ${ }_{1000}^{4}$ of an inch, while the pollen grains were less than 1000 . So that the tube is more than four times the diameter of the grains of pollen which have to pass through it. In some flowers, however, I found the wall of the tube thick and the passage very much smaller. The placenta is not, as in many flowers, a mere point of attachment of the ovules to the ovary, but is large, fleshy, and globular, nearly filling the ovary. It is quite free, except its connection at the base ; and the ovules are embedded in it. It is owing to this, that the ovules cannot be fertilised by the direct action of the poilen grains, as I at first thought possible, but require the intervention of pollen tubes. The substance of the placenta, however, is very spongy and open, so that the pollen tubes can easily penetrate it. In a section of the nearly mature fruit, I have rarely found more than one seed perfect, but small depressions can be seen in the mass of the placenta filled with the debris of the ovules that have not been fertilised. I have been asked once or twice, by young botanists, how it occurs, that plants having many ovules, frequently produce but two or three seeds. I think a transverse section of the fruit of this plant under a low miscroscopic power, would be the best answer that could be given to such an enquiry.

The proportion of perfect and imperfect flowers upon any plant of this species of Myrsine I should think nearly equal. In the first supply I received from Mr. Deane, I found all perfect, the ovaries containing ovules, the anthers full of pollen, except in cases where they had matured and opened; and in most the style a short open tube. I am inclined to think, that the opening of the style increases as the pollen ripens; so that when it is fully ripe, the style is fully open to receive it ; but I merely suggest this, I am not at all sure of it. In the second supply of flowers, from the same tree, I found every one imperfect. Ovaries without ovules, 
and the placenta rudimentary only; stamens, with anthers fully developed, but without pollen; and the style, not a tube, but solid. The genus is said to be, to some extent, Polygamous, and I have no doubt it is, but in the specimens that I have examined, I have found no unisexual flowers, nor even the state of some Lobelias, which, one flower having a perfect pistil with imperfect stamens, while another has perfect stamens with an imperfect pistil, are virtually unisexual. In this plant, however, all the flowers that I have found imperfect, have been so entirely, so far as fertilisation is concerned ; for although the ovary has externally been of the usual form, it has contained no ovules, and though the stamens have borne fully developed anthers, they have been void of pollen.

In every part of the flower, corolla, calyx, ovary, and even far down the pedicel, there are embedded in its substance, peculiar granular masses of a red colour, and varying in size from ${ }_{2000}^{1}$ to $\frac{1}{500}$ of an inch. In the ovary they form a circle embedded in its walls, and even with the assistance of an ordinary pocket lens, any one, not on his guard, may be misled into the belief that they are ovules. An inspection with the microscope, however, soon convinces one to the contrary. Although so embedded in the substance of the flower, they can be picked out separately with a fine needle, leaving a clean cell-like impression behind.

In my former papers I have expressed my belief that, as a rule, flowers are cross-fertilised, either from others on the same plant, or more remotely, from those of a separate plant. Myrsine variabilis is, no doubt, one of the exceptions to that rule. With the corolla so closed as to prevent any pollen bearing insect having access to the stigma (and that not for a time only, but certainly till after the work of fertilisation has been completed), and with the anthers opening directly over the stigma, or mouth of the tubular style, and the appareritly easy access of the pollen to the ovary, I think there can be no doubt that the plant is self-fertilised.

Taking the word in its simple botanical sense, as applied to plants closely fertilised in unopened blossoms, then this plant Myrsine variabilis may be considered as Cleistogamous. I am not, however, 
at all prepared to say, that the whole of this species or even any individual plant of the species is entirely so. It is a very rare thing for a plant to bear cleistogamous flowers only. There are generally some few opening and exposing themselves to crossfertilisation in the usual way, as though nature in any case were loth to depend entirely on self-fertilisation.

\section{Temperature of the body of Echidna Hystrix Cuv.}

By N. de Miklouho Maclay.

During my stay in Brisbane in July 1879, I had an opportunity of getting two Echidna hystrix for the study of the brain. I kept them for several weeks before I had time to begin the anatomical dissection, and they enjoyed the most perfect health, appearing very sleepy during the day, but more active during the night, and leaving a soup plate of milk thickened with some flour quite empty in the mornings. Being at last ready to examine the brain of one of them, and before injecting a dose of hydr. chlor., I took the opportunity of observing the temperature of the body of the animal. A very sensitive thermometer, placed in the cloaca, after lying there undisturbed for ten minutes showed the temperature of $28^{\circ} 3 \mathrm{C}$. (about $83 \circ \mathrm{F}$.)

Believing that the large opening of the cloaca had interfered with the correctness of the observations, I made a small incision, just large enough to introduce the oblong ball of the thermometer into the cavity of the abdomen. The thermometer was left there over ten minutes and showed a temperature of $30^{\circ} 0 \mathrm{C} .\left(86^{\circ} 0 \mathrm{~F}\right.$.)

Not satisfied with this observation, and finding that the observed temperature of the Echidna is much below the known average temperature of the body of Mammalia, I repeated the observation on the other specimen. The second observation was made the 9 th July. The temperature of the air that day was $20^{\circ} 0$ C. $\left(68^{\circ} 0 \mathrm{~F}\right.$.) I made again a small incision, and observed the temperature, in this incision and in the abdominal cavity. 


\section{$2 \mathrm{BHL}$ Biodiversity Heritage Library}

Haviland, E. 1884. "Occasional notes on plants indigenous in the immediate neighbourhood of Sydney. No. 5." Proceedings of the Linnean Society of New South Wales 8, 421-425. https://doi.org/10.5962/bhl.part.28667.

View This Item Online: https://www.biodiversitylibrary.org/item/30993

DOI: https://doi.org/10.5962/bhl.part.28667

Permalink: https://www.biodiversitylibrary.org/partpdf/28667

\section{Holding Institution}

MBLWHOI Library

\section{Sponsored by}

MBLWHOI Library

\section{Copyright \& Reuse}

Copyright Status: NOT_IN_COPYRIGHT

This document was created from content at the Biodiversity Heritage Library, the world's largest open access digital library for biodiversity literature and archives. Visit BHL at https://www.biodiversitylibrary.org. 